\title{
Understanding the minds, problems and aspirations: An untold story about the Egyptian dilemma
}

\author{
Ibrahim Saleh \\ Liaison Officer of the Academic Council on the United Nations System (ACUNS)
}

Accepted 5 November, 2010

\begin{abstract}
Journalism exits in a cultural context, which must be understood within its local socio-political and economic context before it can be accurately evaluated. Egypt is in a state of flux and is considered a classic example of how journalism practice has been affected by the current distributional changes that altered the rules, and positioned journalism at its lowest ebb since the 'Open Door Policy' was initiated by late President Sadat in the 1970s. Problems and challenges of journalism in Egypt are endless that range from ambiguities in the legal framework, deterioration in the professional and skills standards, and the disconnection from reality. Such bleak picture of reality is a logical result of the long years of the usual practice of the state 'turning a blind eye' to everything from finances, to budgets, and circulation claims, as long as it has control over media content in its favor. It is thus, very natural to find journalism is strictly manipulated by state intervention, censorship, legal and regulatory issues. Besides, the increasing religious tone has added further implications on the students enrolled in public institutions. Accordingly, Egyptian journalists are still used to be on the front lines, fighting for basic human rights, while being confronted with oppressive laws and regulations, and certainly would never think of having a future, unless they enter an automatic alliance with the 'Patron State'. But the worst syndrome lies in the huge discrepancy between the standards of living, amenities and facilities available to those, who are from wealthy or poor families, from city or rural backgrounds, or those enrolled in public or private universities. The research methodology will be based on assessment through qualitative research (intensive interviews with media experts and politicians in different African countries) as well as quantitative research (analyzing the level of diversity, efficiency, and comprehensiveness in the coverage of vital issues in governmental versus private media in different countries). The research process will involve a historical analysis of each society in transition. Such multi-step research is hoped to help comprehend the different experiences of imposed democracies in the African countries as well as distinguish between possible, probable, and preferable futures of communication in Africa. Obviously, there is still a lot to do in the research done on the current flagrant gap, debilitating the will for profound social change, between the rhetoric of liberty and the reality of double-standard policies in media studies in societies in transitions like the case in Egypt.
\end{abstract}

Key words: Civil liberty, journalism practices, Egypt, marginal groups, social and political discrepancies, inclusion, exclusion.

\section{INTRODUCTION}

The status of journalism in a country reflects the values of its society, and particularly its political environment. It is impossible to be assessed away from its local socio- political and economic context. While on average, most western societies spend $2-3 \%$ of their GDP on research and development, Arab states dedicate only $0.06 \%$. 
Hence, it is not surprising perhaps that journalism in Egypt is at a very low ebb despite decades of trying to find its niche within the university scholarly environment since the 'Open Door Policy' that was initiated by late President Sadat in the 1970s.

The media in Egypt are still subject to the authoritarian system, where they support and advance the policies of the government. The latter controls the media directly and indirectly through licensing, legal action, and financial assistance. Hence, according to Rugh (2006), Egypt is classified as a transitional media system.

In order to understand the minds, the problems and the aspirations of Egyptians, one must consider the repercussions of the continuous process of legitimizing coercion, political PR-ization of the media, and the use of social taboos to block investigative reporting and the promotion of a bold journalism educational system. This perplexing situation has led to contrasting odds and vicious circles of liberalization and deliberalization.

It is important to note that this paper is part of a new research project initiative that focuses on the link between media and Imposed Democracy Societies in Transition after Independence in African and in the Middle East. The research aims at conducting a comparative study of the politicization of the media during the initial dangerous phases after their implementation.

The research paper aims to investigate further the correlation between political communication, on the one hand, and the possibilities of stipulating nation building in the developing societies, through enhancing cultural change and accelerating a coherent social progress that maintains the harmony of societies in transition, on the other.

The main research thesis is how these societies resist the political instability that might cause their failure, by cross-examining the relation between three key domestic conditions: the persistence of the degree of democracy, the degree of social divisions, and the level of economic prosperity.

Besides, Egypt still suffers from the triple-edged syndrome of illness, poverty, and illiteracy. It is rational, then, to acknowledge that a cornerstone in the current dilemma is the absence of the minimum fundamental requirements of the credentials of journalism education as Napoli (2002) points out. The current fatigue is characterized with lack of philosophical independent press, sufficient budget, and trends advancing individualism and skill premium.

This clearly suggests that there is no shared vision in the country on the way forward. Policy decisions about development and other issues were always subordinate to other overriding goals that took priority. What actually happened is that since the 1952 coup d'état, the Egyptian state has always used its economic power to manipulate the public as a result of being the main provider of everything. This enforced total submission of the public to the state. The social contract was based on a barter deal between the state and the public. The former dispenses with the civil rights of the former while it provides their basic needs as a compromise.

Such relation kept the Egyptian society since the 1952 coup d'état divided between two poles, namely the elite and the militants, while the third sector or grassroots is completely marginalized and neglected. Therefore, the public "sitting in the shadows" reflects their state of being uninvolved.

However, in this phase of cross-roads, and due to many internal and external pressures as well as the increasing role of public emancipation, the Egyptian government has been forced to consider the role of citizens as a public sensor of the economic, social and political issues. New winds of change have gained solid grounds of success.

This is reflected in the introduction of some younger and more business-oriented personalities in the successive cabinets who advocate further radical socio-political and economic measures, though the old guards are doing everything possible to stop the reform.

Real change and development can only be attained by 'loyal opposition', tolerance of opponents, transfer of political power through fair elections, and support of media that emphasize the publics' needs and concerns instead of advocating protocol news. It has become well recognized now that the media hegemony that has prevailed for long failed to appeal to the Egyptian public due to the influence of powerful political and economic elite who imposed heavy tones of censorship and opinionated reporting to justify their corrupt practices. The weak representation of the public voice has resulted from both the self-censorship which is the outcome of long years of oppression and the uncertainty of likely repercussions from the side of the government.

Until recently, the complicated situation in Egypt has created a symptomatic state of "scare and confusion" which sometimes allows a margin of freedom only to relieve the mounting exogenous pressure. Notions like citizenship and democracy can never be fully realized in Egypt without having real concrete insight into the attitudinal context within which the media could be used to outreach remote areas and different segments, especially within a country in which illiteracy, poverty and illness are rampant.

One of the main reasons for the current vague picture of public opinion is the dichotomy between the elite intellectual leaders and agents of change who produce such material, on the one hand, and men of the street who are mainly the ordinary, simple, uneducated, or semi-educated people targeted by these works on the other. The elite often lead while the street follows, but the situation is reversed occasionally with the street erupting with spontaneous demonstrations, especially following important events.

It is thus, believed that assessing the media institution effect is a starting point in organizing any reform for a 
number of reasons. First, the media transmit policies such as deregulation, privatization, or the removal of an export tax. Second, media privatization involves changes in the incentives and rules that govern public and private organizations. Third, many policy changes depend on the discourse presented in the media that can help orient the public into profound socio-political and economic changes. Fourth, the media-specific intents of reform introduce new transaction costs stemming from information asymmetry and bounded rationality that affect audience behavior (Powers, 2003).

This study attempts to transcend the conventional primary analysis of complicated issues to a more technical analysis that explains the data in its sociopolitical and economic context.

\section{Setting the local scene}

\section{The socio-political setting}

Egypt is at the intersection of three overlapping geopolitical circles: Africa, the Arab world, and the Muslim world. Hence, what happens in Egypt resonates beyond its borders. Understanding the Egyptian milieu is integral to formulating a new social contract that would be both valid and reliable.

During the last 14 centuries, the rise and fall of Egypt historically correlated with the rise and fall of the Arab world. Within the Muslim circle, Egypt has always been the base for the Muslim civilization and culture. The Fatimid dynasty ruled the Muslim umma (community) from Cairo. For more than a thousand years, Al-Azhar, one of the oldest universities in the world, has been a magnet and base for Muslim scholars from Morocco to Indonesia.

For the last 200 years, Egypt's experience with dominant foreign powers included the Ottoman Empire (from the sixteenth century to 1914), the French campaign (1798-1801), and the British colonialism (1882-1954) (Baer, 1962, 1969), which makes it not surprising to know that Egyptians learnt to distrust foreigners, especially hegemonic powers. Egyptians have become a collective depository of how much their ancestors suffered at the hands of foreign occupiers (Saleh, 2003).

A turning point occurred in 1948 when the United States recognized Israel on the same day that the provisional Jewish government proclaimed the birth of the state of Israel. And as a result of the defeat of Egypt in the first Arab-Israeli War of 1948, the army took over the Egyptian government in 1952.

Since then, the military has become entrenched in Egyptian politics, which has largely turned into a one-man show over the political process. Only four presidents held office, all from the armed forces: Mohamed Naguib (1953-1954), Gamal Abdul Nasser (1954-70), Anwar Sadat (1970-1981), and Husni Mubarak (1981-present).
In the context of contemporary history, the long experience with hegemonic powers has created a dilemma for Egyptians in modern times. Besides, there must be a consideration of two crucial aspects: Egyptians' pride of their ancient civilization and its fabulous achievements during its long history, on the one hand, and the accumulated mistrust due to the deteriorating conditions in the living standards, the frustration with the militarybased government, as well as the oppressive nature of increasing urbanization and its associated congestion and stress.

\section{The economic setting}

For a long time, the private sector played a weak role in the Egyptian economy and did not significantly participate in political activities. Under both Nasser and Sadat, the state was able to create loyal coalition, supporting some groups at the expense of others. Even after the application of structural adjustment policies, the Egyptian state continued its dependence on the classes and interest groups of the "Open Door Policy" or the infitah era, offering more support to new businessmen and foreign investors (Saleh, 2003).

Throughout the contemporary history of Egypt, the state's economic practices shaped the nature of its political coalitions and its relationships with the different social classes and interest groups. The main difference between the Nasser and Sadat étatist regimes was the focus of Nasser on balancing economic development through import substitution with industrialization strategies to support the most vulnerable groups while Sadat focused on welfare policies at the expense of developmental strategies. The notion of "populism" explains the character of Nasser's regime in the early 1950s but it failed to account for the economic leading actor in both the economy and social welfare.

It is worth mentioning that the intensity of relations between the internal and international elites has led to higher basic goods prices, increased imports, growth of debt, and an expansion of corruption. In addition, such policies have promoted poverty, illiteracy, income inequality, malnutrition, and accelerated deterioration in the living conditions for the majority of poor people. This erosion of state sovereignty has allowed the international institutions to impose their policies regardless of their domestic impact. Such situation has benefited certain groups at the expense of the majority. While it has strengthened new classes, such as new businessmen and other interest groups, it has had a devastating effect upon the general population.

Under these conditions, the new economic powers, represented by such businessmen, have chosen to ally with the state as this of course would grant them the considerable advantage of placing some of their members in the Parliament to support the ruling party and 
existing tendencies in state policy. The relation between the two poles remained in harmony as long as there was conflict of interest between them (Kienle, 1998). Such unevenness in power relations between the state and the larger society has been a crucial barrier to the democratization process in Egypt.

Although, the Egyptian state has retained its hegemonic role, the militant elite during Nasser, was gradually replaced by the business elite during Sadat and Mubarak. This reshaped the constituents of the socialist society into a corporate one. Such transformation has necessitated some modifications in the hegemonic role of the state to cater for the new interest groups.

Questioning the role of the state as a vital actor has become unimportant in contrast to the question of how it should manage the relationships among the different social classes and interest groups. In the absence of a strong civil society, minimizing the role of the state will lead to the dominance of specific interest groups at the expense of society's most vulnerable people. A strong state is vital for development although, it cannot bring about development by itself.

\section{The legal framework}

Theoretically, the Egyptian Constitution and international human right instruments became part of the Egyptian law upon ratification by virtue of article 151 of the Constitution. Article 47 of the Egyptian Constitution promises that the "freedom of opinion shall be guaranteed. Every individual shall have the right to express his opinion and to publicize it verbally, in writing, by photography, or by other means of expression within the limits of the law" (Arab Republic of Egypt: Constitution). Furthermore, Article 19 of the International Covenant on Civil and Political Rights, to which Egypt became a party in 1982, guarantees the right of the freedom of expression, including the "freedom to seek, receive and impart information and ideas of all kinds, regardless of frontiers, either orally, in writing or in print, in the form of art, or through any other media". The Press Law (1996) states that "journalists are independent and not under the authority of anyone" (Arab Republic of Egypt: Constitution). "Within the limits of the law," it further states, "a journalist's opinion or truthful information published by him may not be a reason for a violation of his personal security, and he must not be forced to disclose the sources of his information" (Arab Republic of Egypt: Constitution). However, the reluctance of the Press Syndicate to admit online journalists to its ranks reflects uncertainty on this issue. The E-Signature Law (Law No. 14 of 2004) gives electronic signatures the same legal weight as written signatures. The 2003 Communications Law (Law No. 10 of 2003) places checks on the government's authority to monitor electronic communications.
In reality, such rights are restricted by a series of laws that have a bearing on their application such as the Riotous Assembly Law 15 (1914), the Meetings and Demonstrations Law 14 (1923), the Emergency Law (1958) and the Police Organization Law 109 (1971).

The Riotous Assembly Law 15 (1914) is by nature an exceptional law similar to a martial decree. This law was promulgated during the exceptional circumstances Egypt experienced under the oppression of the British occupation. The Meetings and Demonstrations Law 14 (1923) was passed in the absence of Parliament, and it contains three problematic provisions that flagrantly violate the right to peaceful assembly. First, Article 2 of Law 14 obliges anyone wishing to hold a meeting to inform the security authorities at least three days before the meeting is held. (During election periods, the time is reduced to $24 \mathrm{~h}$ ).

These requirements clearly violate Article 54 of the Constitution. Second, Article 4 of Law 14 enables the police and governors to ban, in advance, the meetings, marches and demonstrations of a political nature held in public roads or squares. Third, the law gives the police and the security forces power to attend and break up meetings. The Police Organization Law 109 (1971) smothers any attempts to exercise the right to peaceful assembly and freedom of opinion (Arab Republic of Egypt: Constitution).

In May 1999, the Egyptian Parliament passed a law (Law No. 153 of 1993) encroaching upon the NGOs' freedom to organize and act. The new law banned private groups from working to influence government policy or union activity. It gave the Ministry of Social Affairs power to disband boards of directors (Arab Republic of Egypt: Constitution). NGOs must seek permission from the government before accepting foreign donations. Following a wave of protests by both Egyptian and international NGOs, the law was found unconstitutional by the Constitutional Court on procedural grounds, and it was suspended. However, the country's older law on NGOs (Law 32 of 1964), which is seen as equally repressive, remains in force.

\section{THEORETICAL PERSPECTIVES}

The current research is conducted in the light of an eclectic conceptually framework encompassing the News Framing Theory, Gadi Wolsfeld's Political Contest Model and Taylor's concept of "groups dynamics".

Indeed, key forms in the political imagination may have profoundly different significances and uses in specific, local sociopolitical contexts. As internationalism is perceived as a mobile set of cultural representations and practices that are supra-local in their significance, they vary in form and meaning from place to place.

Such conceptual framework perceives media analyses follow the assumptions of Herman and Chomsky that 
news discourse reflects the dominant ideological and regime interests of the nation of origin. While the media's national origin does not determine its discourse, it does provide clues to how certain issues are discussed and certain terminology framed. Past studies have shown how use of this phrase varies with nation, region, and historical context, but that one may detect an international consensus forming when the meaning and agenda for world opinion converge across several nations' newspapers.

In this context, one needs to explain the phenomenon of "group think". This phrase was coined in the 1970s by the American psychologist, Irving Janis, to describe a process by which a group can make bad or irrational decisions characterized by uncritical acceptance of a prevailing point of view (Irving, 1972). In a group think situation, each group member attempts to conform his or her opinion to what they believe to be the consensus of the group. This conformity may result in the group ultimately agreeing upon an action that each member might individually consider unwise.

Group think is a severe problem in the Middle East, because it threatens to turn the general public into believers and followers of rituals. Hence, it reduces the communication of the group with outsiders. News coverage influenced by group think may result in the eruption of wrath, where a mob reaction tends to use force and violence to convince non-believers.

Cohen describes this constructed "moral panic" in his book Folk Devils and Moral Panics (1972), which deliberately allows "the manufacture of news". In such processes certain groups are defined as a threat to societal values and interests by stereotypical representations in the mass media. Moral barricades are manned by editors, Muslim religious leaders, politicians and other "right-thinking" people.

In his book Media and Political Conflict: News from the Middle East, Wolsfeld (1997) describes The Political Contest Model and emphasizes that framing places information in a unique context so that certain elements get a greater allocation. This influences the individuals' judgments.

The four variables of "group dynamics" identified by Taylor (1982) explain how public opinion functions. The first variable is one's opinion on an issue; the second is one's perception of the predominant public opinion; the third is one's assessment of the likely future course of public opinion; the fourth is one's willingness to support other signs of commitment. This explains how media content is shaped by the readiness of the public to adopt a certain view due to its needs and how the level of publics' reaction is subject to many mediating factors.

A typical and direct result of media distortions, untruth, evasions, and biases collectively produced and maintained witting journalistic lies. In 1988, psychologistlawyer Mark Snyderman and political scientist Stanley Rothman provided strong evidence that the general public receive a highly distorted view of opinions from the mainstream news media.

Keeping this in mind, many Egyptians feel that their ideas are misrepresented in the media; hence, they refrain from voicing out their views and remain silent in the face of public falsehood - a social illness of "living within a lie."

Such conceptual framework attempts to relate the literature review to the context of the Egyptian experience. When the researcher referred to Wolsfield, the study attempted to draw a big picture perspective of the media that are being jeopardized by the state to serve its political agenda.

As a result of such dim reality, the Egyptian public find themselves in a fix between a conflicting public agenda to what is represented in media. This represents a situation of shadowing the majority needs to cater for the minority interests and preferences. Therefore, the research papers attempts to address this complicated issue on two levels: the general public, through the national representative survey, and the media personnel, through intensive interviews.

\section{RESEARCH METHODOLOGY}

Due to the need for expansion in the surveys investigating people's opinions in a country that lived for years without anyone sensemaking what they want, aspire and think about anything, a study that used both qualitative and quantitative research methods to find answers to the following questions:

1. What is the view of the Egyptian Public versus the views of journalists in Egypt?

2. What are the risks facing the practice of Journalists in Egypt?

3. What are the impediments facing journalism field in Egypt?

4. How is it possible to improve the journalism field to help solve the current problems and reflect the aspirations of the desperate Egyptian publics?

In its first stage, a survey of 1221 respondents was conducted during the period between February 4th and February 8th, 2006. This survey was sponsored by the Information and Decision Support Centre (IDSC). The sample chosen for the study was a stratified random sample which covered the national, urban, and major metropolitan areas. A database of telephone subscribers in all the twenty-seven governorates (provinces) of Egypt was utilized. The percentages of participants were chosen in a way to keep the original distribution of the population in the main geographic regions of Egypt Urban governorates (18\%), Lower Egypt (45\%) and Upper Egypt (37\%).

Statistical analysis confirms a hypothesis related to the 
Table 1. Mapping the media habits in Egypt.

\begin{tabular}{llccc}
\hline Variable & & $\begin{array}{c}\text { Radio } \\
\text { listening }\end{array}$ & $\begin{array}{c}\text { TV } \\
\text { viewership }\end{array}$ & Readership \\
\hline Gender & Male & $3.90 \%$ & $96.70 \%$ & $18.30 \%$ \\
& Female & $3.90 \%$ & $96.70 \%$ & $13.70 \%$ \\
Age & $(15-30)$ & $4 \%$ & $94.50 \%$ & $37.70 \%$ \\
& $(30-40)$ & $4 \%$ & $94.50 \%$ & $9.60 \%$ \\
Educational level & Primary education & $5.50 \%$ & $\mathrm{NA}$ & $9 \%$ \\
& Higher education & $5.50 \%$ & $\mathrm{NA}$ & $21.30 \%$ \\
Employment & Private sector & $3.80 \%$ & $\mathrm{NA}$ & $15.30 \%$ \\
status & Govt. sector & $7.90 \%$ & $\mathrm{NA}$ & $15.30 \%$ \\
\hline
\end{tabular}

Table 2. How media deal with current issues?

\begin{tabular}{llll}
\hline Current issues & Rank & Media success & Media failure \\
\hline Corruption & First & $63 \%$ & $31.9 \%$ \\
Unemployment & Second & $59 \%$ & $38.7 \%$ \\
Privatization & Third & $55 \%$ & $45 \%$ \\
Increase in cost of living & Fourth & $51 \%$ & $26.9 \%$ \\
\hline
\end{tabular}

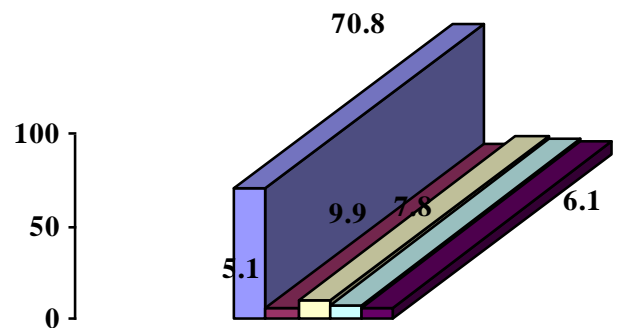

$\square$ Unempolyment $\square$ Housing $\square$ Poverty $\square$ Political Restructuring $\square$ Removing Subsidization

Figure 1. Public agenda.

nature of the cultural orality of Egyptians. As the survey emphasized that $(96.7 \%)$ of Egyptian watch TV regardless age, educational level, employment, occupation (Table 1). In another indicator of media habits that radio listening is a dying media in Egypt, in the 60s, and 70s was the most widespread with an average $(3.9 \%)$, while reading is the luxury of the elite with an average of (16\%) with a slight difference between gender preferences; males (18.3\%), and females(13.7\%). In a nutshell, media habits in Egypt emphasizes the significance of media regardless the influence of other factors (Figure 1).

The analysis revealed that $70.8 \%$ of the public believe that unemployment (disguised, mismatched, not having jobs) is the major social problem by far that threatens the whole societal fabric. Primary analysis would indicate that the other problems, like housing and poverty, are insignificant to the public or that they do not perceive the removal of subsidization as a serious problem that occurred after advocating a corporate society (Figure 2). However, one explanation could be that unemployment is the crucial setback that leads to other issues poverty, inability of getting houses and the need for subsidization. Overcoming this problem is the first step on the way of solving the other problems.

The survey ranked as the most urgent matter in public agenda with $(63 \%)$ say that media succeeded in dealing with this issue, while $(31.9 \%)$ rejected this view and said that it is a complete failure (Table 2). It is worth mentioning that gender differences play a significance role in that regard, though both genders generally reject the idea. As males have a higher rate of rejection (34.9\%), while the percentage goes down to $(30 \%)$. As for the age 

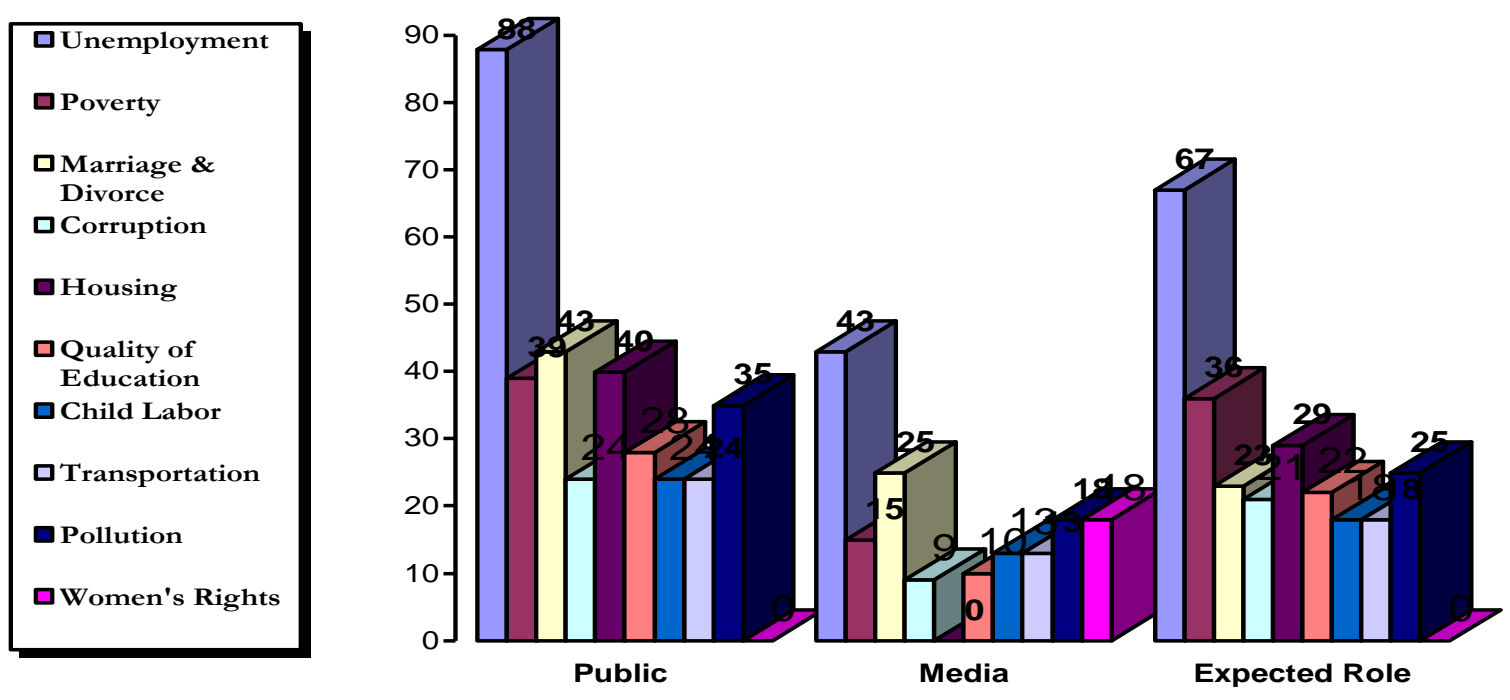

Figure 2. Comparison between the government agenda, media agenda and the expected media role.

factor, $(28 \%)$ of the sample in all age groups say that media failed to address the issue. However, the age group (50+) is the relatively speaking the most accepting group of the sample (42.5\%). Besides, the educational level also plays a role in the level of acceptance of the media coverage, especially among students enrolled in the primary and secondary schools with a rate of acceptance of $(38.5 \%)$. In reference to the occupational factor, $40.5 \%$ of employees working in the government sector approves the coverage, while $43.3 \%$ of employees working in the private sector disapproves the media coverage of the issue.

Statistical analysis confirms that Egyptians still believe in media as a tool for change and development, especially in dealing with the issue of unemployment. In that regard, gender differences do not make any influence, yet age is decisive factors as there is positive relations between younger generations have the most trust in media $(54.5 \%)$, however the educational level has a negative correlation in that regard as $(45 \%)$ of the sample in the higher education lacks trust in media functionality. Besides, the occupational sector has its implications too, as the highest segment of employees $(42.1 \%)$ in the private sector distrusts media in its current structure.

The third burning issue for Egyptians is "Privatization". In general, $(55 \%)$ of the sample approved the media coverage, while (45\%) disapproved it. Gender differences resonated in the answers due to the fact that $(39 \%)$ of males, and (43\%) of the females reject the way the issue is covered in national media. The age difference is another crucial indicator in that regard. As the age group $(50+)$ is the most accepting to the media coverage with a rate of acceptance reaching (19.9\%), while the age group between (30-40) is considered the least accepting the media portrayal with a rate of $(45.5 \%)$. As for education as a factor, sample from the higher education group reject the portrayal of the coverage $(46 \%)$, while $(21.5 \%)$ of the sample that belongs to primary education has a tendency to approve it. Occupational is very logic to affect how to perceive the media coverage. As $(30 \%)$ of the sample working in the government sector react and have skeptical concerns about the coverage, while $(21.5 \%)$ of the sample working in the private sector tends to accept the coverage of the topic.

With regard to the increase in the cost of living, which comes at the fourth rank in the significance of the topics in the media agenda, 51\% approved the coverage, while $26.9 \%$ had skeptical views of such coverage. Besides, the statistical analysis of the sample excluded any gender difference in the way the Egyptians have developed their standing points of such coverage. However, the age element has its strong implications as age group (50+) is the most accepting of the media coverage with a rate reaching $(25.8 \%)$, but the age group $(15-20)$ is the most rejecting one with a rate exceeding (40.2\%). The occupational status of the status did not have clear implications as generally (28.5\%) of the total sample reject the current media coverage, and makes their level of acceptance correlated to the potential of changing content and quality of the media. As for the educational level, one finds that $28 \%$ of the sample belonging to the primary education is the most accepting and supporting the current media coverage, while $14.7 \%$ of the sample belonging to higher education has the least tendency to accept the media portrayal with a long list of concerns.

The second research method is Intensive Interviews of 200 personal face-to-face interviews $(35-40 \mathrm{~min})$ conducted with media professionals at their work place and with media university students at their public or private universities/or at their homes from. The interviews took place during the period from August 11th to 

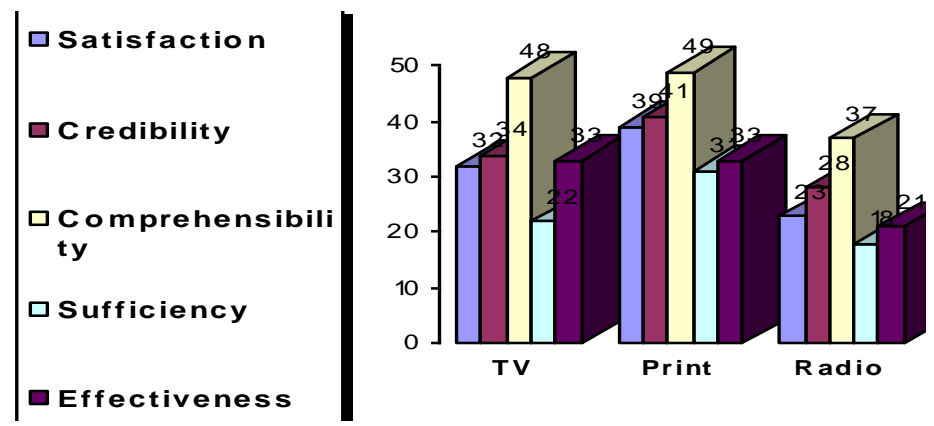

Figure 3. Media evaluation.
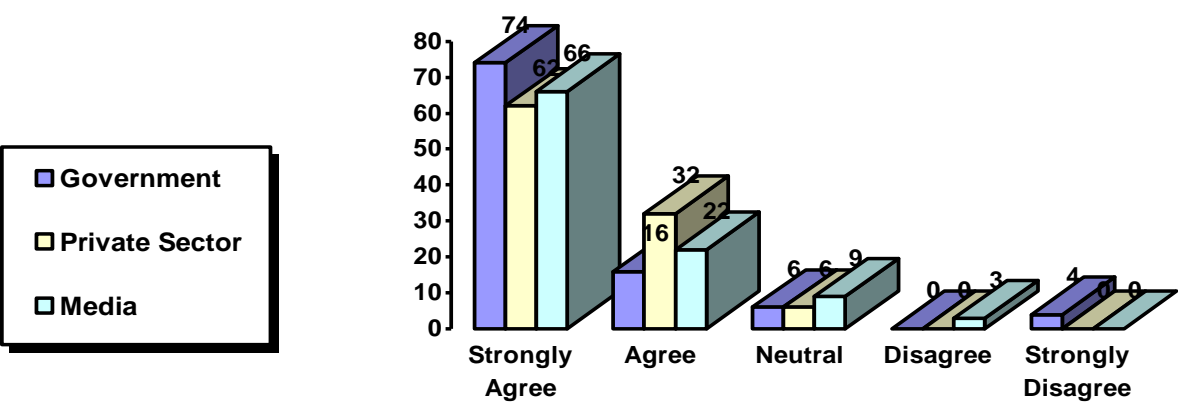

Figure 4. Who is responsible for the current situation?

September 22nd, 2005. The study was sponsored by the British Council in Cairo.

Figure 3 illustrates a discrepancy between the priorities of the public agenda and the media agenda. For instance, while unemployment has a great priority in the public agenda $(88 \%$ of the respondents see that it represents a major problem), only $43 \%$ of the informants think it is sufficiently covered in the media agenda while $67 \%$ of the respondents presume that it should be given greater priority in the media. Similarly, while $40 \%$ of the informants see housing as another quite serious problem, none of the respondents see that it is given any serious attention in the media and $29 \%$ believe that the media should give it more attention.

Another interesting finding was the issue of the empowerment of women. The results of the study revealed that $18 \%$ of the respondents believe that this topic is prioritized in the media while both the public perception of the problem and people's expectancy of how the media should deal with it are zero. A primary analysis of such figures would suggest that the issue of the empowerment of women is not important for the public or that there is a sort of discrimination against women. However, technical analysis would explain the percentage as a result of two overlapping factors. First, the public are aware that women are already granted equal rights. Second, they believe that while the government agenda is prioritizing this issue through a national campaign, advocated by the first lady, there are more urgent problems related to the basic needs of people that are worthy of government attention.

Levels of satisfaction, effectiveness, sufficiency, credibility and comprehensibility

As Figure 4 indicates, in general, all the feedback with regard to the different variables does not exceed $49 \%$, which means that the performance of the different media in general is not pleasing. There is a dichotomy between media habits and media appreciation. For example, the results reflect that the highest levels of satisfaction are related to print media while the national survey states that the most followed medium is T.V. - 97\% of Egyptians watch it. Nevertheless, only $48 \%$ of the respondents are satisfied with the comprehensibility of the TV.

$90 \%$ of the respondents emphasized the responsibility of the government for the current fixation and for the lack of civil liberties. $74 \%$ of them strongly blame the government for that while $16 \%$ of them blame it with direct and indirect criticism of the absence of social enterprise structures in society (Figure 5 ).

As Figure 5 illustrates, a very close percentage of the respondents said that the media can help improve the situation basically through highlighting the reasons for change $(27 \%)$ and engaging the street $(26 \%) .18 \%$ of the sample suggested the disclosure of information as one way through which the media can help in the current 

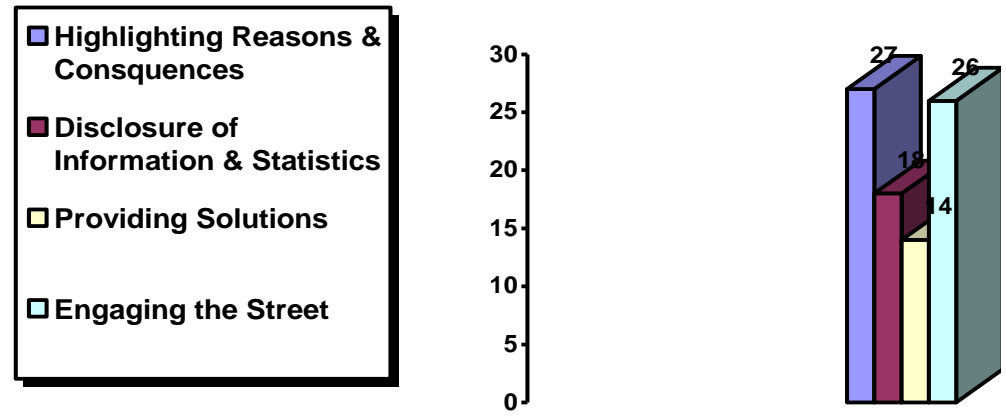

Figure 5. Ways through which media can help improve the situation.

critical situation. This may be justified by the publics' dependence on other alternative sources of information that have emerged such as blogging, etc. Only $14 \%$ suggested providing solutions as an aspired media strategy since the public are no longer interested in ready made solutions offered by the media or by those responsible. They rather look for their active participation in solving their problems through polling, etc.

Both research methods indicated that there are a number of criteria that might have affected the current media habits including the diversity of media content, the possibility of publics' identification with it, the potential of media explanation of the prospects and concerns of the different issues as well as media capability of offering solutions and pragmatic scenarios for development.

On the one hand, it was found out that diversity in media content is a primary factor in shaping public media habits in all the groups of informants regardless of their gender, age group, level of education or working condition and regardless of the news approach used. On the other hand, offering solutions appeared to have the least impact in shaping public behavior and media habits for the same reason clarified by people in the interviews.

\section{DISCUSSION AND CONCLUSION}

The street in Egypt is seldom empowering the expression of public opinion and collective sentiment, because it is always perceived as a brute force expressed in riots and mob violence. However, the Egyptian street still represents a complex entity wherein sentiments and outlooks are formed, spread and expressed in a unique fashion. However, the authorities keep on trying to exert a pervasive power over public spaces through police patrols and similar authorities. Students at Cairo University, for example, often stage protest marches inside the campus. However, the moment they decide to come out into the street (where the Israeli embassy is located), riot police are immediately and massively deployed to encircle the demonstrators, push them into a corner away from public view and keep the protest a local event.

Both research methods have confirmed the hypothesis regarding the failure of Egyptian media to be responsive to the citizens and to reflect their needs besides their little accountability or openness to the people. On the one hand, private media are weak (or owned by politicians/ their families) though they may appear 'vibrant' to outsiders. Such media do not demand openness or accountability of the government. They do not serve as 'watchdogs'. On the other hand, public media are still (after transition) captured by the state/ruling party; so again, they make no demands on leadership but serve as spokesmen/propagandists.

The Egyptian media are still unable to take a stand, initiate legislation, or reject one coming from the authorities. The current study revealed that there is a huge gap between public agenda and media agenda. Hence, there is a knowledge discrepancy in the Egyptian society, and whenever available it is usually derived from interpersonal communication. Given people's heavy dependence on TV viewing and realizing the fact that news media talk about developmental ideas all the time, this indicates that there is a sort of disorder.

Media personnel should reconsider how to effectively tackle all issues in a way that appeals to the public and gains their confidence. Another important finding of this study is that the public no longer accept ready-made solutions offered by the media. They rather need to be part of the decision making process. Having said so, there is an urgent need to inclusion of marginal groups in the media representation, depiction, and engagement. Besides, diversity in media content is a key factor in attracting the publics and giving a sense of more reliability through tackling the issues from different perspectives.

In that regard, the 'political will to reform' is the most important determinant of democratic and economic reform. There is a clash between the personal interest and public welfare. MPs are selected by party leaders and not by the people they represent, so candidates are imposed on constituencies.

The problem in Egypt is sometimes the issue of 
resources, but it is often the lack of vision, and serious steps to attain it. Hence, the cornerstone here is the urgency to have a progressive developmental plan boosts a sound civil service that is able to design and implement programs without political interference.

Fighting the widely spread corruption and nepotism; enhancing the freedom of expression, citizen journalism, and democratization; as well as empowering street politics of the grassroots (the third sector or the marginal groups that are completely disregarded by the state) rather than prioritizing the interests of the elite and the military are the foundations of having a civil society.

In that end, sticking to the self-motivated private selfinterests rather than the national well-being will never allow the public a chance to voice their problems and concerns. It will always let the masses be at least relatively powerless and voiceless. There is an urgent need for supporting the process that promotes change and aids education and critical thinking as well as the other projects that explicitly help people learn to coordinate and organize opposition to vested interests. Empowering the civil liberties can gradually help reduce or end government control of the public media and of information flow.

\section{Endnotes:}

Imposed democracy regimes are democratic governments installed in their establishment, promotion, and maintenance by a foreign power. Here, "imposed" is used as synonyms with the term "stimulated."

\section{REFERENCES}

Arab Republic of Egypt: Constitution, Law Library of Congress, (29 December 2006) [cited 23 June 2006]. Available from the World Wide Web: http://www.loc.gov/law/guide/egypt.html.

Baer G (1962). A history of landownership in modern Egypt, 1800-1950. Oxford: Oxford University Press.

Baer G (1969). Studies in the social history of modern Egypt. Chicago: University of Chicago Press.

Balinski ML, Young HP (1974). A new method for congressional apportionment. PNAS 71(11):4602-4606.

Cohen S (1972). Folk devils and moral panics: Creation of mods and rockers. London: Mac Gibbon and Kee.

Irving J (1972). Victims of groupthink. Boston: Houghton Mifflin?

Kienle E (1998). More than a response to Islamism: The political deliberalization of Egypt in the 1990s. Middle East J. 52(2):219-235.

Napoli, J. (2002) International journalism education at the end of history, starting in Albania. Journal. Mass Commun. Educ. 57 (3): 260-270.

Rugh WA (2006). American encounters with Arabs: The "soft power" of U.S. public diplomacy in the Middle East. Westport, CT: Praeger.

Saleh I (2003). Unveiling the truth about the Middle Eastern media. Privatization in Egypt: Hope or dope? Cairo: CMC Press.

Satloff $R$ (2002). The Arab 'street' poses no real threat to US. Newsday.

Taylor A (1982). The Arab balance of power system. Syracuse, N.Y.: Syracuse University Press.

Wolsfeld G (1997). The media and political conflict: News from the Middle East. New York: Cambridge University Press. 